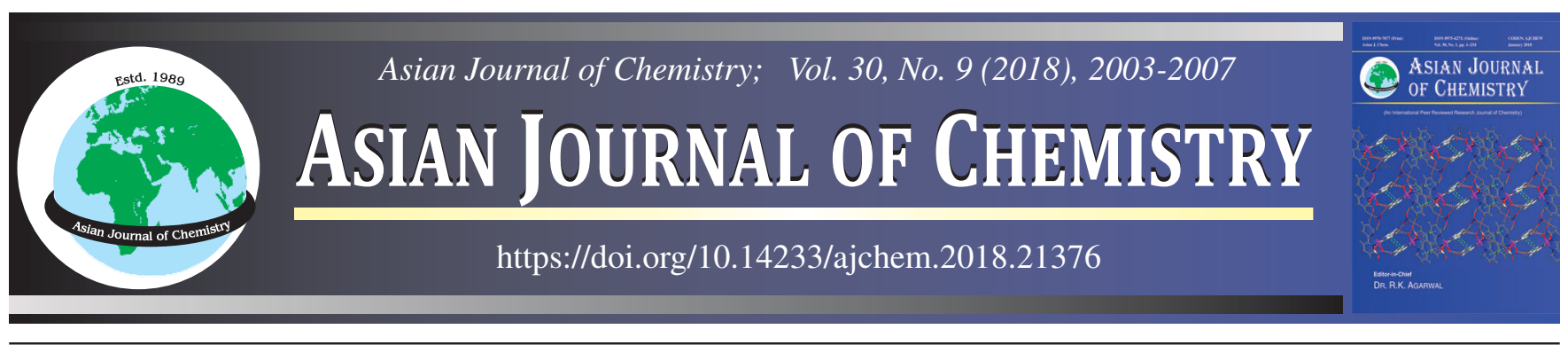

\title{
Synthesis and Characterization of Potential Pharmacopeial Impurities of Oseltamivir: An Antiviral Drug
}

\section{Rajasekhar Ponduri ${ }^{1,2, *}$, Pramod Kumar ${ }^{2}$, Lakshmana Rao Vadali ${ }^{1}$, Komaraiah Aelugu $^{1}$ and Kishore Matcha ${ }^{1}$}

\author{
${ }^{1}$ Mylan Laboratories Limited, Bollaram, Jinnaram (Mandal), Medak-502 325, India \\ ${ }^{2}$ Jawaharlal Nehru Technological University-Hyderabad, College of Engineering, Centre for Chemical Sciences \& Technology, Institute of \\ Science and Technology, Kukatpally, Hyderabad-500 085, India
}

*Corresponding author: E-mail: rajasekharponduri123@gmail.com

| Impurities of oseltamivir phosphate were synthesized from chiral epoxide (1) in a simpler and much feasible synthetic approach in seven steps accounting to $8.2 \%$ overall yield. The nucleophilic addition of $\mathrm{N}_{3}$ (highly regioselective and stereoselective) in the first and third stage of the synthesis has been tailored and the reaction conditions were optimized.

Keywords: Oseltamivir, Impurities, Antiviral, Aziridine.

\section{INTRODUCTION}

The spreading of avian flu in winged animals increased the chance of undeviating contamination in people. Till now, transmission through individual to individual has been only from time to time and aligned with close human contact [1]. At present, hostile to flu medicines comprise of two classes of medications: M2 protein inhibitors (amantadine and rimantadine) and neuraminidase inhibitors (oseltamivir and zanamivir) [2-4]. As a class, neuraminidase inhibitors are successful against all neuraminidase subtypes and, hence, against all strains of flu. This is a key point in pestilence and pandemic readiness and an imperative favourable position over the M2 protein inhibitors which are successful just against touchy strains of flu A2. Among every single antiviral medication, oseltamivir is the prescribed antiviral to treat patients tainted with avian flu (H5N1) incorporating chemoprophylaxis in high-hazard populaces [5]. To protect people from the attack of pandemic human influenza or H5N1 Avian flu, it is recommended that oseltamivir phosphate (Tamiflu, Fig. 1) should be manufactured and stocked in every country all over the world [6,7]. As a continuous requirement of this drug in bulk stock, in recent years, many researchers have reported many synthetic sequences towards the preparation of oseltamivir phosphate [8-18]. Furthermore, in order to improve the efficacy oseltamivir drug,<smiles>CCOC(=O)C1=C[C@H](OC(CC)CC)[C@H](NC(C)=O)[C@H](N)C1</smiles>

Fig. 1. Structure of tamiflu

continuous efforts has been put into action for the development of new derivatives of oseltamivir [19-21].

The existence of impurities in an active pharmaceutical ingredient can have a substantial influence on the quality and safety of the drug pr oducts. Therefore, it is essential to understand the impurity profile of the API to be castoff in the manufacturing of the drug product. A level of impurity profile $\geq 0.1$ $\%$ [22]. Guidelines was endorsed by International Conference on Harmonization ( $\mathrm{ICH}$ ) for the identification and characterization of all impurities.In this perspective, we have been taken to synthesize and characterization of the two potential WHO impurities: 5-acetylamino-4-amino-3-(1-ethyl propoxy)cyclohex-1-enecarboxylic acid ethylester (9, WHO Impurity-F) and 5-acetylamino-4-amino-3-(1-ethyl propoxy)cyclohex-1-enecarboxylic acid (10, WHO impurity-A) (Fig. 2).

This is an open access journal, and articles are distributed under the terms of the Creative Commons Attribution-NonCommercial 4.0 International (CC BY-NC 4.0) License, which allows others to copy and redistribute the material in any medium or format, remix, transform, and build upon the material, as long as appropriate credit is given and the new creations are licensed under the identical terms. 


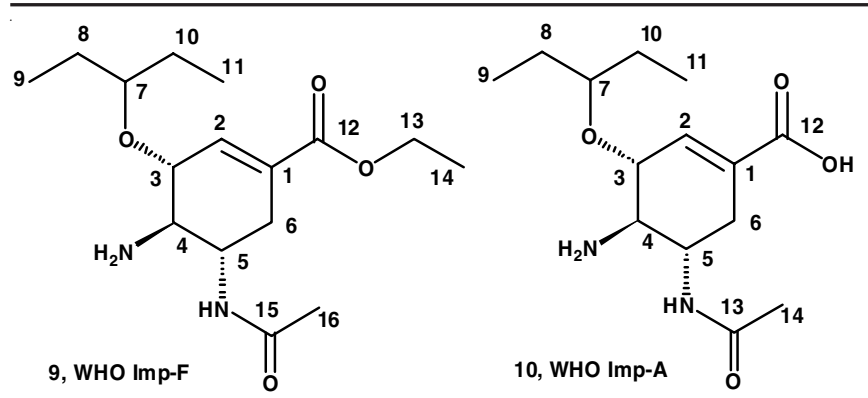

Fig. 2. Structures of WHO impurity-F and WHO impurity-A

\section{EXPERIMENTAL}

Thin-layer chromatography (TLC) were run on silica gel $60 \mathrm{~F}_{254}$ precoated plates $(0.25 \mathrm{~mm}$, Merck) and spots were visualized inside an UV cabinet under short UV. ${ }^{1} \mathrm{H}$ NMR spectra were recorded on Bruker $300 \mathrm{MHz}$ Advance NMR spectrometer at $300 \mathrm{MHz}$ TMS as an internal standard. Mass spectra were obtained using an Agilent 1100 Series LC-MSD-TRAPSL system.

Ethyl-(3R,4S,5R)-5-azido-4-hydroxy-3-(pentan-3yloxy)cyclohex-1-ene-1-carboxylate (2): To a stirred solution of epoxide 1 ( $30 \mathrm{~g}, 118.1 \mathrm{mmol}$ ) in a mixture of methanol $(920 \mathrm{~mL})$ and water $(120 \mathrm{~mL})$ was added sodium azide $(38.3$ $\mathrm{g}, 50.05 \mathrm{mmol})$ followed by ammonium chloride $(13.64 \mathrm{~g}$, $259.8 \mathrm{mmol})$. The reaction mixture was heated to $65-70{ }^{\circ} \mathrm{C}$ for $16 \mathrm{~h}$. After completion of the reaction, the solvents were stripped from the reaction mixture under vacuum up to 4.0 volumes. Water $(120 \mathrm{~mL})$ was added to the reaction mixture and the product was extracted with ethyl acetate $(2 \times 200 \mathrm{~mL})$. The organic layer was evaporated under vacuum and the residue was purified by column chromatography to obtain azide 2 . Light brown liquid; Yield: $70 \%$; Anal. calcd (\%) for $\mathrm{C}_{14} \mathrm{H}_{23} \mathrm{~N}_{3} \mathrm{O}_{4}$ : C, 56.55; H, 7.80; N, 14.13. Found: C, 56.58; H, 7.85; N, 14.01. ${ }^{1} \mathrm{H} \mathrm{NMR}\left(\mathrm{CDCl}_{3}, 300 \mathrm{MHz}\right): \delta 0.98(\mathrm{t}, J=6.6 \mathrm{~Hz}, 6 \mathrm{H}), 1.30$ $(\mathrm{t}, J=7.2 \mathrm{~Hz}, 3 \mathrm{H}), 1.49-1.63(\mathrm{~m}, 4 \mathrm{H}), 2.21-2.30(\mathrm{~m}, 1 \mathrm{H}), 2.72$ (d, $J=6.6 \mathrm{~Hz}, 1 \mathrm{H}), 2.80-2.87(\mathrm{~m}, 1 \mathrm{H}), 3.40-3.48(\mathrm{~m}, 1 \mathrm{H}), 3.71-$ $3.80(\mathrm{~m}, 1 \mathrm{H}), 3.84-3.91(\mathrm{~m}, 1 \mathrm{H}), 4.11-4.14(\mathrm{~m}, 1 \mathrm{H}), 4.25$ (q, $J=6.6 \mathrm{~Hz}, 2 \mathrm{H})$; 6.83-6.85 (m, 1H); ESI-MS: $m / z, 298.2(\mathrm{M}+\mathrm{H})$.

Ethyl-(1R,5R,6R)-5-(pentan-3-yloxy)-7-azabicyclo[4.1.0]hept-3-ene-3-carboxylate (3): To a solution of Azide 2 $(25 \mathrm{~g}, 84.17 \mathrm{mmol})$ in acetonitrile $(200 \mathrm{~mL})$, triphenyl phosphine (27.56 g, $105.21 \mathrm{mmol}$ ) was added portion wise (exothermic) over a period of $15 \mathrm{~min}$ at room temperature. The reaction mixture was heated to $80^{\circ} \mathrm{C}$ for $3 \mathrm{~h}$. The solvent was evaporated and the residue was purified by column chromatography to obtain aziridine [3]. Pale yellow syrupy liquid; Yield: $63 \%$; Anal. calcd (\%) for $\mathrm{C}_{14} \mathrm{H}_{23} \mathrm{NO}_{3}$ : C, 66.37; H, 9.15; N, 5.53. Found: C, 66.34; H, 9.17; $\mathrm{N}, 5.58 .{ }^{1} \mathrm{H}$ NMR (DMSO- $\left.d_{6}, 300 \mathrm{MHz}\right): \delta 0.90(\mathrm{t}, J=6.4 \mathrm{~Hz}$, $6 \mathrm{H}), 1.20(\mathrm{t}, 3 \mathrm{H}, J=7.4 \mathrm{~Hz}), 1.36-1.59(\mathrm{~m}, 4 \mathrm{H}), 2.17$ (brs, $1 \mathrm{H})$, 2.32 (brs, 1H), 2.40 (brs, 1H), 3.38 (t, $J=7.2 \mathrm{~Hz}, 1 \mathrm{H}), 4.15$ (q, $J$ $=7.2 \mathrm{~Hz}, 2 \mathrm{H}), 4.18$ (brs, $1 \mathrm{H}), 6.61$ (d, $J=7.2 \mathrm{~Hz}, 1 \mathrm{H})$; ESI-MS: $\mathrm{m} / \mathrm{z}, 254.1(\mathrm{M}+\mathrm{H})$.

Ethyl-(3R,4R,5S)-4-amino-5-azido-3-(pentan-3yloxy)cyclohex-1-ene-1-carboxylate (4): To a stirred solution of aziridine 3 (13 g, $51.38 \mathrm{mmol})$ in DMF (150 mL) was added sodium azide $(16.69 \mathrm{~g}, 102.76 \mathrm{mmol})$ followed by ammonium chloride (13.64 g, $259.8 \mathrm{mmol}$ ). The reaction mixture was heated to $65-70^{\circ} \mathrm{C}$ for $16 \mathrm{~h}$. The solvents were stripped from the reaction mixture under vacuum up to 4 vol. Water (130 $\mathrm{mL}$ ) was added to the reaction mixture and the product was extracted with ethyl acetate $(2 \times 100 \mathrm{~mL})$. The organic layer was evaporated under vacuum and the residue was purified by column chromatography to obtain amine 4. Pale-yellow syrupy liquid; Yield:70 \%; Anal. calcd (\%) for $\mathrm{C}_{14} \mathrm{H}_{24} \mathrm{~N}_{4} \mathrm{O}_{3}$ : C, 56.74; $\mathrm{H}, 8.16$; N, 18.90. Found: C, 56.71; H, 8.12; N, 18.95. ${ }^{1} \mathrm{H}$ NMR $\left(\mathrm{CDCl}_{3}, 300 \mathrm{MHz}\right): \delta 0.98(\mathrm{t}, J=6.4 \mathrm{~Hz}, 6 \mathrm{H}), 1.30(\mathrm{t}, J=7.2$ $\mathrm{Hz}, 3 \mathrm{H}), 1.45-1.67$ (m, 4H), 2.25-2.36 (m, 1H), 2.84-2.96 (m, 2H), 3.37-3.51 (m, 2H), 3.86-3.90 (m, 1H), 4.26 (q, $J=7.2$ $\mathrm{Hz}, 2 \mathrm{H}), 6.80$ (brs, 1H); ESI-MS: m/z $297.2(\mathrm{M}+\mathrm{H})$.

tert-Butyl (1R,2R,6S)-4-(ethoxycarbonyl)-6-azido-2(pentan-3-yloxy)cyclohex-3-enylcarbamate (5): Boc anhydride $(5.12 \mathrm{~g}, 50.61 \mathrm{mmol})$ was added dropwise to a solution of compound 4 (10 g, $33.78 \mathrm{mmol})$ in dichloromethane (100 $\mathrm{mL})$ and triethylamine $(8.1 \mathrm{~g}, 37.11 \mathrm{mmol})$ at $0{ }^{\circ} \mathrm{C}$. The reaction mixture was allowed to stir at room temperature for $16 \mathrm{~h}$. After completion of the reaction, checked by TLC, water $(100 \mathrm{~mL})$ was added to the reaction mixture and stirred for $15 \mathrm{~min}$. The organic layer was separated and evaporated under vacuum, the residue was purified by column chromatography to obtain N-protected Boc compound 5. White solid; Yield: $65 \%$; Anal. calcd (\%) for $\mathrm{C}_{19} \mathrm{H}_{32} \mathrm{~N}_{2} \mathrm{O}_{5}$ : C, 57.56; H, 8.14; N, 14.13. Found: C, 57.60; H, 8.16; N, 14.00. ${ }^{1} \mathrm{H} \mathrm{NMR}\left(\mathrm{CDCl}_{3}, 300 \mathrm{MHz}\right): \delta 0.92(\mathrm{t}, J=6.6$ $\mathrm{Hz}, 6 \mathrm{H}), 1.30$ (t, $J=7.2 \mathrm{~Hz}, 3 \mathrm{H}), 1.43$ (s, 9H), 1.45-1.57 (m, 4H), 2.15-2.36 (m, 1H), 2.74-2.87 (m, 1H), 3.07-3.18 (m, 1H), 3.31$3.40(\mathrm{~m}, 1 \mathrm{H}), 4.21(\mathrm{q}, J=7.2 \mathrm{~Hz}, 2 \mathrm{H}), 4.4-4.5$ (brs, $1 \mathrm{H}), 4.8-$ 4.9 (brs, $1 \mathrm{H}), 6.75$ (brs, $1 \mathrm{H}) ;{ }^{13} \mathrm{C} \mathrm{NMR}\left(300 \mathrm{MHz}, \mathrm{DMSO}-d_{6}\right)$ : $\delta 9.3,9.5,14.1,25.6,26.2,28.3$ (3C), 30.7, 57.4, 58.3, 60.9, 73.4, 79.8, 82.2, 128.0, 138.1, 155.2, 165.8; ESI-MS $\mathrm{m} / \mathrm{z}$ for $[\mathrm{M}+\mathrm{H}]$-calculated (found) for $\mathrm{C}_{19} \mathrm{H}_{32} \mathrm{~N}_{4} \mathrm{O}_{5}$ : (397.6) 397.3

Ethyl-(3R,4R,5S)-5-amino-4-[(tert-butoxycarbonyl)amino]-3-(pentan-3-yloxy)cyclohex-1-ene-1-carboxylate (6): To a solution Boc-compound 5 (7 g, $17.67 \mathrm{mmol})$ in THF $(70 \mathrm{~mL})$ was added triphenyl phosphine $(5.5 \mathrm{~g}, 21.21 \mathrm{mmol})$ in portions at $25-30{ }^{\circ} \mathrm{C}$. The reaction mixture was stirred at $25-30{ }^{\circ} \mathrm{C}$ for $16 \mathrm{~h}$. The reaction mixture was diluted with water $(70 \mathrm{~mL})$ and extracted with ethyl acetate $(2 \times 50 \mathrm{~mL})$ and evaporated under vacuum to obtain the crude compound 6. The crude compound was utilized in the next step without any purification. Anal. calcd (\%) for $\mathrm{C}_{19} \mathrm{H}_{34} \mathrm{~N}_{4} \mathrm{O}_{5}$ : C, 61.60; H, 9.25; N, 7.56. Found: C, 61.57; H, 9.20; N, 7.52.

Ethyl-(3R,4R,5S)-5-(acetylamino)-4-[(tert-butoxycarbonyl)amino]-3-(pentan-3-yloxy)cyclohex-1-ene-1carboxylate (7): A mixture of amine 6 (7 g, $18.89 \mathrm{mmol})$, potassium carbonate $(3.91 \mathrm{~g}, 28.33 \mathrm{mmol})$ and acetic anhydride $(2.14 \mathrm{~mL}, 22.67 \mathrm{mmol})$ in THF $(70 \mathrm{~mL})$ was stirred at room temperature for $4 \mathrm{~h}$. Water $(56 \mathrm{~mL})$ was added to the reaction mixture and extracted with ethyl acetate twice $(2 \times 42 \mathrm{~mL})$ and evaporated under vacuum, the residue was purified by column chromatography to obtain acetyl compound 7. Pale-yellow syrupy liquid; Yield: $60 \%$; Anal. calcd (\%) for $\mathrm{C}_{21} \mathrm{H}_{36} \mathrm{~N}_{2} \mathrm{O}_{6}$ : C, 61.14; H, 8.80; N, 6.79. Found: C, 61.19; H, 8.76; N, 6.82. ${ }^{1} \mathrm{H}$ NMR $\left(\mathrm{CDCl}_{3}, 300 \mathrm{MHz}\right): \delta 0.94(\mathrm{t}, J=6.6 \mathrm{~Hz}, 6 \mathrm{H}), 1.28(\mathrm{t}, J$ $=7.2 \mathrm{~Hz}, 3 \mathrm{H}), 1.43(\mathrm{~s}, 9 \mathrm{H}), 1.46-1.58(\mathrm{~m}, 4 \mathrm{H}), 1.94(\mathrm{~s}, 3 \mathrm{H})$, 2.25-2.31 (m, 1H), 2.72-2.79 (m, 1H), 3.38-3.42 (m, 1H), 3.72$3.78(\mathrm{~m}, 1 \mathrm{H}), 3.93-3.96(\mathrm{~m}, 1 \mathrm{H}), 4.23$ (q, $J=7.2 \mathrm{~Hz}, 2 \mathrm{H}), 4.69$ 
(brs, $1 \mathrm{H}), 6.58$ (brs, 1H), 6.78 (brs, $1 \mathrm{H}){ }^{13} \mathrm{C}$ NMR $(300 \mathrm{MHz}$, DMSO- $\left.d_{6}\right): \delta 9.2,9.5,14.0,23.0,25.8,26.2,28.2(3 \mathrm{C}), 30.4$, $48.5,55.8,60.7,75.6,79.4,82.5,129.2,137.3,156.7,165.6$, 170.3; ESI-MS $m / z$ for $[\mathrm{M}+\mathrm{H}]$-calculated (found) for $\mathrm{C}_{21} \mathrm{H}_{36} \mathrm{~N}_{2} \mathrm{O}_{6}$ : 413 (413.3).

Ethyl-(3R,4R,5S)-5-(acetylamino)-4-amino-3-(pentan3-yloxy)cyclohex-1-ene-1-carboxylate (WHO-Imp-F, 9): To a solution of acetyl compound 7 (6 g, $14.56 \mathrm{mmol})$ and dichloromethane $(60 \mathrm{~mL})$, cooled to $0-5^{\circ} \mathrm{C}$, was slowly added trifluoroacetic acid $(1.67 \mathrm{~mL}, 21.8 \mathrm{mmol})$. The reaction mixture was stirred at $25-30{ }^{\circ} \mathrm{C}$ for $16 \mathrm{~h}$. After completion of reaction, checked by TLC, the reaction mixture cooled to $0-5^{\circ} \mathrm{C}$ and basified with saturated $\mathrm{NaHCO}_{3}$ solution and extracted with dichloromethane $(2 \times 42 \mathrm{~mL})$ and evaporated under vacuum, the residue was purified by column chromatography to obtain WHO-Imp-F, 9. White solid; Yield: $70 \%$; Anal. calcd (\%) for $\mathrm{C}_{16} \mathrm{H}_{28} \mathrm{~N}_{2} \mathrm{O}_{4}$ : C, 61.51; H, 9.03; N, 8.97. Found: C, 61.55; H, 9.06; N, 8.95. IR $\left(v_{\max }, \mathrm{KBr}, \mathrm{cm}^{-1}\right): 1281(-\mathrm{C}-\mathrm{N}), 1714,1703(\mathrm{C}=\mathrm{O}), 3071$ (alkene, $-\mathrm{HC}=\mathrm{C}-), 3383(-\mathrm{N}-\mathrm{H}) ;{ }^{1} \mathrm{H}-\mathrm{NMR}\left(\mathrm{CDCl}_{3}, 300 \mathrm{MHz}\right): \delta 0.89$ $(\mathrm{t}, J=6.6 \mathrm{~Hz}, 6 \mathrm{H}), 1.21(\mathrm{t}, J=7.2 \mathrm{~Hz}, 3 \mathrm{H}), 1.38-1.58(\mathrm{~m}, 4 \mathrm{H})$, 1.63 (brs, 2H), 1.84 (s, 3H), 1.95-2.04 (m, 1H), 2.49-2.57 (m, $1 \mathrm{H}), 2.66-2.72(\mathrm{~m}, 1 \mathrm{H}), 3.33-3.44(\mathrm{~m}, 1 \mathrm{H}), 3.67-3.72(\mathrm{~m}, 1 \mathrm{H})$, $3.85(\mathrm{~d}, J=7.2 \mathrm{~Hz}, 1 \mathrm{H}), 4.16(\mathrm{q}, J=7.2 \mathrm{~Hz}, 2 \mathrm{H}), 6.66(\mathrm{~s}, 1 \mathrm{H})$, 7.79 (d, $J=7.5 \mathrm{~Hz}, 1 \mathrm{H}) ;{ }^{13} \mathrm{C}$ NMR (300 MHz, DMSO- $\left.d_{6}\right): \delta$ 9.2, 9.5, 14.0, 22.8, 25.3, 25.7, 30.3, 48.8, 54.8, 78.2, 80.0, 128.3,137.8,165.6, 169.1; ESI-MS $\mathrm{m} / \mathrm{z}$ for $[\mathrm{M}+\mathrm{H}]$-calculated (found) for $\mathrm{C}_{16} \mathrm{H}_{28} \mathrm{~N}_{2} \mathrm{O}_{4:} 313$ (313.2).

(3R,4R,5S)-5-(Acetylamino)-4-[(tert-butoxycarbonyl)amino]-3-(pentan-3-yloxy)cyclohex-1-ene-1-carboxylic acid (8): To a stirred solution of acetyl compound 7 (15.0 g, $36.3 \mathrm{mmol})$ in a mixture of methanol $(15 \mathrm{~mL})$ and THF $(60 \mathrm{~mL})$ was slowly added a pre-mixed solution of lithium hydroxide monohydride $(15.25 \mathrm{~g}, 363.3 \mathrm{mmol})$ in water $(45 \mathrm{~mL})$. The reaction mixture was stirred at room temperature $7 \mathrm{~h}$. After the completion of the reaction, checked by TLC, the solvents were stripped from the reaction mixture under vacuum. The aqueous layer was acidified with citric acid solution and the product was extracted with ethylacetate $(2 \times 25 \mathrm{~mL})$. The organic layer was evaporated under vacuum and isolated compound $\mathbf{8}$. Off white solid; Yield: $70 \%$; Anal. calcd (\%) for $\mathrm{C}_{19} \mathrm{H}_{32} \mathrm{~N}_{2} \mathrm{O}_{6}$ : C, 59.36; H, 8.39; N, 7.29. Found: C, 59.33; H, 8.42; N, 7.25. ${ }^{1} \mathrm{H} \mathrm{NMR}\left(\mathrm{CDCl}_{3}, 300 \mathrm{MHz}\right)$ : $\delta 0.85(\mathrm{t}, J=6.6 \mathrm{~Hz}, 6 \mathrm{H}), 1.29-1.50(\mathrm{~m}, 4 \mathrm{H}), 138(\mathrm{~s}, 9 \mathrm{H}), 1.76$ (s, 3H), 2.06-2.16 (m, 1H), $2.38-2.50(\mathrm{~m}, 1 \mathrm{H}), 3.33-3.42(\mathrm{~m}$, 2H), 3.83-3.88 (m, 1H), 4.08-4.10 (m, 1H), 6.56 (brs, 1H), 6.67 $(\mathrm{d}, J=6.2 \mathrm{~Hz}, 1 \mathrm{H}), 7.70(\mathrm{~d}, J=7.4 \mathrm{~Hz}, 1 \mathrm{H}) ;{ }^{13} \mathrm{C}$ NMR $(300$ $\left.\mathrm{MHz}, \mathrm{DMSO}-d_{6}\right): \delta 9.1,9.2,22.7,25.4,25.7,25.9,28.2(3 \mathrm{C})$, 30.5, 47.7, 55.9, 75.1, 77.2, 81.3, 129.3,137.8, 155.8, 167.2, 168.6; ESI-MS $m / z$ for $[\mathrm{M}+\mathrm{H}]$-calculated for $\mathrm{C}_{16} \mathrm{H}_{28} \mathrm{~N}_{2} \mathrm{O}_{4}: 407.2$ (M+Na) found: 407.2.

(3R,4R,5S)-5-(acetylamino)-4-amino-3-(pentan-3-yloxy)cyclohex-1-ene-1-carboxylic acid (WHO-Imp-A, 10): To a mixture of compound $\mathbf{8}(3.5 \mathrm{~g}, 9.103 \mathrm{mmol})$ in dichloromethane $(35 \mathrm{~mL})$ was added IPA. $\mathrm{HCl}(15 \mathrm{~mL})$, dropwise at $0-5$ ${ }^{\circ} \mathrm{C}$. The reaction mixture was stirred for $5 \mathrm{~h}$ at $25-30{ }^{\circ} \mathrm{C}$. The solvent was evaporated and the residue was purified by ethyl acetate and IPE and isolated compound WHO-Imp-A, 10. Off white solid; Yield: $80 \%$; Anal. calcd (\%) for $\mathrm{C}_{14} \mathrm{H}_{24} \mathrm{~N}_{2} \mathrm{O}_{4}$ : C, 59.13; H, 8.51; N, 9.85. Found: C, 59.17; H, 8.53; N, 9.90. IR
$\left(\mathrm{KBr}, v_{\max }, \mathrm{cm}^{-1}\right): 1316(-\mathrm{C}-\mathrm{N}), 1651(\mathrm{C}=\mathrm{O}), 3085$ (alkene -C-H), 3434, 3277 (-NH/-OH); ${ }^{1} \mathrm{H}$ NMR $\left(\mathrm{CDCl}_{3}, 300 \mathrm{MHz}\right): \delta 0.84-$ $0.89(\mathrm{t}, J=6.6 \mathrm{~Hz}, 6 \mathrm{H}), 1.35-1.62(\mathrm{~m}, 4 \mathrm{H}), 1.83(\mathrm{~s}, 3 \mathrm{H}), 1.91-$ 2.02 (m, 1H), 2.50-2.51 (m, 1H), 2.69-2.75 (m, 1H), $3.41(\mathrm{t}, J$ $=7.2 \mathrm{~Hz}, 1 \mathrm{H}), 3.68-3.75(\mathrm{~m}, 1 \mathrm{H}), 3.88-3.90(\mathrm{~m}, 1 \mathrm{H}), 6.60(\mathrm{~s}$, $1 \mathrm{H}), 7.88$ (d, $J=7.2 \mathrm{~Hz}, 1 \mathrm{H}) ;{ }^{13} \mathrm{C}$ NMR (300 MHz, DMSO- $\left.d_{6}\right)$ : $\delta$ 9.3, 9.6, 22.8, 25.7, 25.8, 31.3, 48.0, 54.8, 76.9, 79.5, 133.2, 133.5, 168.5, 169.3; ESI-MS $\mathrm{m} / z$ for $[\mathrm{M}+\mathrm{H}]$-calculated for $\mathrm{C}_{14} \mathrm{H}_{24} \mathrm{~N}_{2} \mathrm{O}_{4}$ : 285, found: $307(\mathrm{M}+\mathrm{Na})$.

\section{RESULTS AND DISCUSSION}

The synthesis of two potential WHO impurities of oseltamivir phosphate, (i) ethyl-(3R,4R,5S)-5-(acetylamino)-4-amino3-(pentan-3-yloxy)cyclohex-1-ene-1-carboxylate (WHOIMP-F, 9) and (ii) (3R,4R,5S)-5-(acetylamino)-4-amino-3(pentan-3-yloxy)cyclohex-1-ene-1-carboxylic acid (WHOIMP-A, 10) is illustrated in Scheme-I. These two impurities were prepared starting from epoxide compound 1 [6,7].

The ring opening of epoxide 1 was carried out in presence of sodium azide, ammonium chloride in methanol:THF at 65$70{ }^{\circ} \mathrm{C}$ for $16 \mathrm{~h}$ produced azide-hydroxy 2 . Reduction of azide $\mathbf{2}$ followed by cyclization in presence of triphenyl phosphine in acetonitrile at $80{ }^{\circ} \mathrm{C}$ for $3 \mathrm{~h}$ produced aziridine 3 [23-25]. Ring opening of aziridine 3 [26] in presence of $\mathrm{NaN}_{3}, \mathrm{NH}_{4} \mathrm{Cl}$ in methanol:THF, DMF at $65-70{ }^{\circ} \mathrm{C}$ for $16 \mathrm{~h}$ yielded azideamine 4. Bocylation of azide-amine 4 in presence of Boc anhydride, triethyl amine in dichloromethane at room temperature for $16 \mathrm{~h}$ yielded N-Boc-azidecompound 5. Reduction of NBoc-azide 5 was carried out in presence of triphenyl phosphine in $\mathrm{THF}$ at $25-30{ }^{\circ} \mathrm{C}$ for $16 \mathrm{~h}$ produced $\mathrm{N}$-Boc-amine 6 . Acetylation of N-Boc-amine $\mathbf{6}$ was done in the presence of acetic anhydride, potassium carbonate in THF at room temperature for $4 \mathrm{~h}$ gave compound 7. De-bocylation of compound 7 in presence of trifluoroacetic acid in dichloromethane, at 25-30 ${ }^{\circ} \mathrm{C}$ for $16 \mathrm{~h}$ resulted in the formation of impurity WHO-Imp-F, 9 [27]. Initial attempts to prepare WHO Imp-A, 10 by $\mathrm{LiOH}$ hydrolysis of WHO-Imp-F, 9 was unsuccessful mainly due to its high soluble property in water and difficulty in isolating the product. Therefore, as an alternative approach, Boc-protected ethyl ester compound 7 was hydrolyzed in presence of $\mathrm{LiOH}$ and isolated compound 8. After purification, it was directly used in the next step. Boc de-protection of compound $\mathbf{8}$, in presence of IPA $\cdot \mathrm{HCl}$ resultant in the formation of desired compound WHO-Imp-A, 10.

The structural determination of newly synthesized WHOImp-F, 9 and WHO-Imp-A, 10 was established by ${ }^{1} \mathrm{H}$ NMR, ${ }^{13} \mathrm{C}$ NMR, mass and IR techniques. Characterization of ethyl (3R,4R,5S)-5-(acetylamino)-4-amino-3-(pentan-3-yloxy)cyclohex-1-ene-1-carboxylate (WHO-Imp-F, 9): ${ }^{1} \mathrm{H}$ NMR description: The protons resonating at $1.21 \mathrm{ppm}$ as triplet $(3 \mathrm{H})$ and $4.16 \mathrm{ppm}$ as quartet $(2 \mathrm{H})$ is assigned to the ethyl ester group. The protons resonating at $0.84-0.89$ as multiplet $(6 \mathrm{H}), 1.38$ 1.58 as multiplet $(4 \mathrm{H})$ and $3.67-3.72 \mathrm{ppm}$ is assigned to the pental group. The protons resonating at $6.66 \mathrm{ppm}(1 \mathrm{H}), 1.84$ ppm $(3 \mathrm{H})$ as singlets corresponds to olefinic proton and acetyl group, respectively. The $\mathrm{D}_{2} \mathrm{O}$ exchangeable protons of $-\mathrm{NH}_{2}$ and $-\mathrm{NH}$ groups resonated at 1.63 and $7.79 \mathrm{ppm}$. The protons associated with the cyclohexene ring resonated at 1.95-2.04 


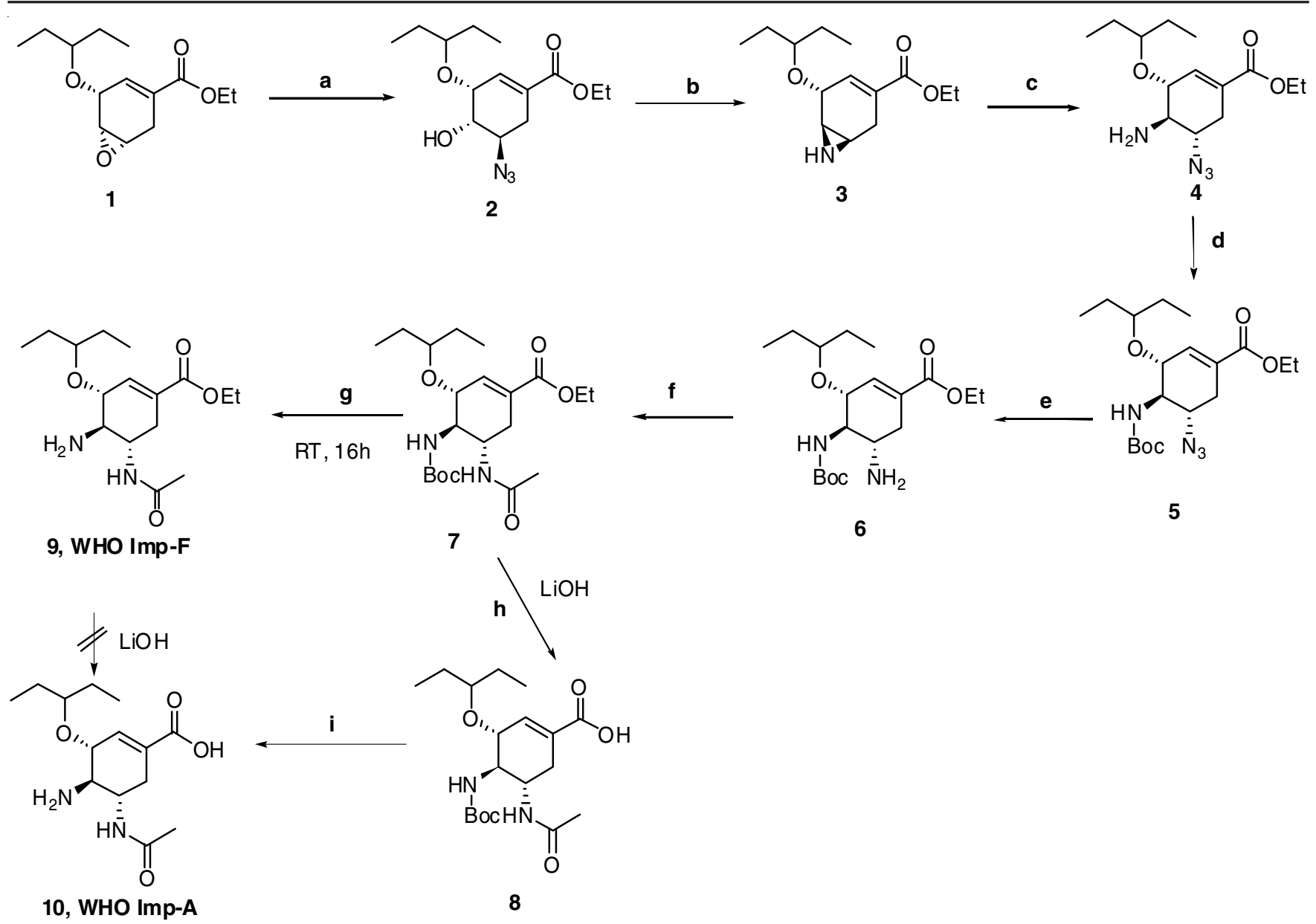

Scheme-I: Synthesis of oseltamivir impurities WHO-Imp-A and WHO-Imp-F

and 2.49-2.57 ppm (- $\mathrm{CH}_{2}$ adjacent to ethyl ester group), 2.66$2.72 \mathrm{ppm}$ (-CH flanked to acetyl group), 3.33-3.44 ppm (-CH flanked to $-\mathrm{NH}_{2}$ group) and $3.85 \mathrm{ppm}$ (-CH flanked to -O-pentanal group). Thus, above ${ }^{1} \mathrm{H}$ NMR description is in agreement with the desired number of protons in the structure.

${ }^{13}$ C NMR: The carbon signals resonating at $169.1 \mathrm{ppm}$, $165.6 \mathrm{ppm}$ is assigned to the characteristic carbonyl groups viz., ethylester carbonyl (C-12) and acetyl carbonyl group (C-15), respectively. The carbon signals resonating at 128.3 and 137.8 $\mathrm{ppm}$ is assigned to oelfin carbons (C-2 and C-1), respectively. The methylene carbons signals (- $\mathrm{CH}_{2}, \mathrm{C}-6, \mathrm{C}-8, \mathrm{C}-10$ and $\left.\mathrm{C}-13\right)$ resonated in the region $25.3 \mathrm{ppm}, 25.7 \mathrm{ppm}, 30.3 \mathrm{ppm}$ and $60.2 \mathrm{ppm}$, respectively and were confirmed by carbon DEPT experiment. The methyl carbons viz., C-9, C-11, C-14 and C16 resonated at 9.2, 9.5, 14.0 and $22.8 \mathrm{ppm}$, respectively while tertiary carbon signals of cyclohexene ring such as C-5, C-4, C-3 and C-7 resonated at 48.8, 54.8, 78.2 and 80.0 ppm, respectively. Thus, above ${ }^{13} \mathrm{C}$ NMR description is in agreement with the desired number of carbons in the structure.

IR: IR data suggest that strong characteristic bands appeared at $3383,1714,1634$ and $1281 \mathrm{~cm}^{-1}$ are due to the following characteristic groups $-\mathrm{NH},-\mathrm{C}=\mathrm{O},-\mathrm{C}=\mathrm{C}-,-\mathrm{C}-\mathrm{N}$ associated with the desired compound.

Mass spectra: Mass spectrum of WHO Imp-F, 9 showed $\mathrm{M}+1$ peaks at $\mathrm{m} / \mathrm{z}, 313$ in positive mode and is in agreement with its molecular formula. Similarly, the structural determin- ation of WHO Imp-A, 10 was established as per the above description.

\section{Conclusion}

The synthesis and characterization of two potential WHO listed impurities of oseltamivir phosphate viz., (i) ethyl-(3R, 4R,5S)-5-(acetylamino)-4-amino-3-(pentan-3-yloxy)cyclohex-1-ene-1-carboxylate (WHO-IMP-F, 9) and (ii) (3R,4R,5S)5-(acetylamino)-4-amino-3-(pentan-3-yloxy)cyclohex-1-ene1-carboxylic acid (WHO-IMP-A, 10) are demonstrated. These impurities were characterized by IR, mass and NMR spectroscopic techniques. Synthesis of these impurities helps in obtaining a good-quality output of API and formulation, also helps in establishing the impurity profile of API by understanding the cause of its origin and control.

\section{ACKNOWLEDGEMENTS}

The authors express their thanks to Analytical Division of Mylan Laboratories Ltd., India for providing analytical and spectral facilites.

\section{CONFLICT OF INTEREST}

The authors declare that there is no conflict of interests regarding the publication of this article. 


\section{REFERENCES}

1. K. Ungchusak, P. Auewarakul, S.F. Dowell, R. Kitphati, W. Auwanit, P. Puthavathana, M. Uiprasertkul, K. Boonnak, C. Pittayawonganon, N.J. Cox, S.R. Zaki, P. Thawatsupha, M. Chittaganpitch, R. Khontong, J.M. Simmerman and S.N. Chunsutthiwat, Engl. J. Med., 352, 333 (2005); https://doi.org/10.1056/NEJMoa044021.

2. A.N. Moscona, Engl. J. Med., 353, 1363 (2005); https://doi.org/10.1056/NEJMra050740

3. E.D. Clercq, Nat. Rev. Drug Discov., 5, 1015 (2006); https://doi.org/10.1038/nrd2175.

4. E.D. Clercq, Nat. Rev. Microbiol., 2, 704 (2004); https://doi.org/10.1038/nrmicro975.

5. H.J. Schünemann, S.R. Hill, M. Kakad, R. Bellamy, T.M. Uyeki, F.G. Hayden, Y. Yazdanpanah, J. Beigel, T. Chotpitayasunondh, C. Del Mar, J. Farrar, T.T. Hien, B. Özbay, N. Sugaya, K. Fukuda, N. Shindo, L. Stockman, G.E. Vist, A. Croisier, A. Nagjdaliyev, C. Roth, G. Thomson, H. Zucker and A.D. Oxman, Lancet Infect. Dis., 7, 21 (2007); https://doi.org/10.1016/S1473-3099(06)70684-3.

6. J. Kongkamnerd, L. Cappelletti, A. Prandi, P. Seneci, T. Rungrotmongkol, N. Jongaroonngamsang, P. Rojsitthisak, V. Frecer, A. Milani, G. Cattoli, C. Terregino, I. Capua, L. Beneduce, A. Gallotta, P. Pengo, G. Fassina, S. Miertus and W. De-Eknamkul, Bioorg. Med. Chem., 20, 2152 (2012); https://doi.org/10.1016/j.bmc.2012.01.026.

7. L.-D. Nie, X.-X. Shi, K.H. Ko and W.-D. Lu, J. Org. Chem., 74, 3970 (2009); https://doi.org/10.1021/jo900218k.

8. M. Federspiel, R. Fischer, M. Hennig, H.-J. Mair, T. Oberhauser, G. Rimmler, T. Albiez, J. Bruhin, H. Estermann, C. Gandert, V. Göckel, S. Götzö, U. Hoffmann, G. Huber, G. Janatsch, S. Lauper, O. Röckel-Stäbler, R. Trussardi and A.G. Zwahlen, Org. Process Res. Dev., 3, 266 (1999); https://doi.org/10.1021/op9900176.

9. S. Abrecht, P. Harrington, H. Iding, M. Karpf, R. Trussardi, B. Wirz and U. Zutter, Chimia, 58, 621 (2004); https://doi.org/10.2533/000942904777677605.

10. L.D. Nie, X.X. Shi, N. Quan, F.F. Wang and X. Lu, Tetrahedron Asymm., 22, 1692 (2011); https://doi.org/10.1016/j.tetasy.2011.09.014.

11. S. Raghavan and V.S. Babu, Tetrahedron, 67, 2044 (2011); https://doi.org/10.1016/j.tet.2011.01.064.

12. L.D. Nie, W. Ding, X.X. Shi, N. Quan and X. Lu, Tetrahedron Asymm., 23, 742 (2012); https://doi.org/10.1016/j.tetasy.2012.05.014.

13. H.K. Kim and K.J.J. Park, Tetrahedron Lett., 53, 1561 (2012); https://doi.org/10.1016/j.tetlet.2012.01.017.
14. L.D. Nie, F.F. Wang, W. Ding, X.X. Shi and X. Lu, Tetrahedron Asymm., 24, 638 (2013); https://doi.org/10.1016/j.tetasy.2013.04.016.

15. A.I. Kalashnikov, S.V. Sysolyatin, G.V. Sakovich, E.G. Sonina and I.A. Shchurova, Russ. Chem. Bull., 62, 163 (2013); https://doi.org/10.1007/s11172-013-0024-2.

16. N.-G. Li, Z.-H. Shi, Y.-P. Tang, Q.-P. Shi, W. Zhang, P.-X. Zhang, Z.-X. Dong, W. Li, J.-A. Duan, K. Pratsch, R. Wellhausen and H. Seitz, Curr. Org. Chem., 18, 16 (2014); https://doi.org/10.1016/j.cbpa.2013.10.024.

17. B. Kongkathip, S. Akkarasamiyo and N. Kongkathip, Tetrahedron, 71, 2393 (2015); https://doi.org/10.1016/j.tet.2015.02.081.

18. P. Laborda, S.-Y. Wang and J. Voglmeir, Molecules, 21, 1513 (2016); https://doi.org/10.3390/molecules21111513.

19. Y. Xie, D. Xu, B. Huang, X. Ma, W. Qi, F. Shi, X. Liu, Y. Zhang and W. $\mathrm{Xu}$, J. Med. Chem., 57, 8445 (2014); https://doi.org/10.1021/im500892k.

20. R.M. Neri-Bazán, J. García-Machorro, D. Méndez-Luna, L.E. TolentinoLópez, F. Martínez-Ramos, I.I. Padilla-Martínez, L. Aguilar-Faisal, M.A. Soriano-Ursúa, J.G. Trujillo-Ferrara, M.J. Fragoso-Vázquez, B.L. Barrón and J. Correa-Basurto, Eur. J. Med. Chem., 128, 154 (2017); https://doi.org/10.1016/j.ejmech.2017.01.039.

21. Z. Wang, L.P. Cheng, X.H. Zhang, W. Pang, L. Li and J.L. Zhao, Bioorg. Med. Chem. Lett., 27, 5429 (2017); https://doi.org/10.1016/j.bmcl.2017.11.003

22. S.Q. Wang, X.C. Cheng, W.L. Dong, R.L. Wang and K.C. Chou, Biochem. Biophys. Res. Commun., 401, 188 (2010 https://doi.org/10.1016/j.bbrc.2010.09.020.

23. International Conference on Harmonisation of Technical Requirements for Registration of Pharmaceuticals for Human Use, ICH Harmonised Guideline for Elemental Impurities Q3D; Current Step 4 version, 16 December (2014)

24. H. Osato, I.L. Jones, A. Chen and C.L.L. Chai, Org. Lett., 12, 60 (2010); https://doi.org/10.1021/o19024716.

25. J.C. Rohloff, K.M. Kent, M.J. Postich, M.W. Becker, H.H. Chapman, D.E. Kelly, W. Lew, M.S. Louie, L.R. McGee, E.J. Prisbe, L.M. Schultze, R.H. Yu and L. Zhang, J. Org. Chem., 63, 4545 (1998); https://doi.org/10.1021/jo980330q.

26. R. Oliyai, L.C. Yuan, T.C. Dahl, K.Y. Swaminathan, K.-Y. Wang and W.A. Lee, Pharm. Res., 15, 1300 (1998); https://doi.org/10.1023/A:1011964529805.

27. M. Junwal, A. Sahu, T. Handa, R.P. Shah and S. Singh, J. Pharm. Biomed. Anal., 62, 48 (2012); https://doi.org/10.1016/j.jpba.2012.01.001. 